PITTSBURGH JOURNAL OF TECHNOLOGY LAW \& POLICY

VOLUME 17

SPRING 2017

\title{
TABLE OF CONTENTS
}

\section{STAFF ARTICLE SERIES}

Wearable Evidence: Why the Pennsylvania Judiciary Should Require a Warrant to Search Wearable Technology

Pat Augustine

3-D Printed Guns: A Developing Technology with Dangerous Potential Jonathan Danielczyk

Walk Out Technology: The Need to Amend Section 5 of the Federal Trade Commission Act to Protect Consumer Privacy and Promote

Corporate Transparency

Alexandra Menosky 
PITTSBURGH JOURNAL OF TECHNOLOGY LAW \& POLICY

VOLUME 17

SPRING 2017

2016-2017 EDITORIAL STAFF

Board of Editors

Editor-in-Chief

J.D. MASON

Lead Executive Editor

VANESSA NICHOLLE GRIFFITH

Lead Articles Editor

COLLEEN A. MALLICK

MATTHEW A. DELUZIO

Research Editors

ALEXIS WHEELER CHRISTOPHER WOODWARD

ADAM SHIRER

PATRICK AUGUSTINE JON DANIELCZYK

Faculty Advisor

MICHAEL J. MADISON

\section{Executive Editors \\ JENNA M. DECKER \\ SARAH SABA}

Managing Editor

ALEX POSSINO

\section{Lead Research Editor JOSEPH E. BRENNER}

Alumni Chair STEVEN J. WILDBERGER

Articles Editors ADAM GARRET ALEXANDRA MENOSKY

\section{Staff Editors}

VICTOR SAMUEL KUSTRA NATALIE MANGENE KEIRSTYN MARCUCCI
NICHOLAS PAHUTA ALEXANDER M. SIDMAN

Document Technology Center

Director

LUANN M. DRISCOLL

\section{Staff}

VICKI DiDOMENICO

KAREN KNOCHEL

DARLEEN MOCELLO

BARB SALOPEK 


\section{General Publication Information}

\section{SUBSCRIBER INFORMATION}

The Pittsburgh Journal of Technology Law \& Policy (JTLP) is a student-produced journal of contemporary legal topics involving technology of all kinds. This Journal is published twice per year, one in the fall and one in the spring, by the University Library System, University of Pittsburgh.

Correspondence. Address all correspondence regarding permission to reprint to Managing Editor, Pittsburgh Journal of Technology Law \& Policy, University of Pittsburgh School of Law, 3900 Forbes Ave., Pittsburgh, PA 15260; tlpjournal@gmail.com. Authors: see section entitled Information for Authors.

Form. The text and citations in the JTLP conform generally to THE BLUEBOOK: A UNIFORM SYSTEM OF CITATION (Columbia Law Review Ass'n et al. eds., 20th ed. 2015). Please cite this issue of the Pittsburgh Journal of Technology Law \& Policy as 17 PGH. J. TeCH. L. \& POL'Y (2017).

\section{INFORMATION FOR AUTHORS}

The Editorial Board of the Pittsburgh Journal of Technology Law \& Policy invites the submissions of unsolicited manuscripts. Submissions may include articles, essays, case notes, or comments concerning any aspect of the relationship between technology and the law. If any portion of a manuscript has been previously published, the author should so indicate. On certain scholarly works, JTLP will publish concurrently with another Journal.

Format. Authors may submit manuscripts in electronic or hardcopy form, though electronic submissions are strongly encouraged. Electronic submissions should be sent as attachments in Microsoft Word format to pittjtlp.submissions@gmail.com. Authors should submit double-spaced, single-sided manuscripts with generous margins. We regret that submissions cannot be returned. Authors should retain an exact copy of any material submitted.

Citations. All citations should conform to THE BLUEBOOK: A UNIFORM SYSTEM OF CITATION (Columbia Law Review Ass'n et al. eds., 20th ed. 2015). Additionally, the author should include his or her credentials, including full name, degrees earned, academic or professional affiliations, and citations to previously published articles.

Copyrighted Material. If manuscript contains any copyrighted table, chart, graph, illustration, photograph, or more than eight lines of text, the author must obtain written permission from the copyright holder for use of the material. A photocopy of such written permission should accompany the submission. 
Mailing Address. The Pittsburgh Journal of Technology Law \& Policy (JTLP) strongly prefers electronic submissions be sent as Microsoft Word attachments to pittjtlp.submissions@gmail.com. However, JTLP also accepts hardcopy manuscripts sent to:

Executive Editor

Pittsburgh Journal of Technology Law \& Policy (JTLP)

University of Pittsburgh School of Law

3900 Forbes Avenue

Pittsburgh, PA 15260

Donors. The Pittsburgh Journal of Technology Law \& Policy is a nonprofit organization and welcomes donations. Donors are recognized appropriately for their contributions. For more information, contact Pittsburgh Journal of Technology Law \& Policy, University of Pittsburgh School of Law, 3900 Forbes Ave., Pittsburgh, PA 15260, or email tlpjournal@gmail.com. 